\title{
Comparison of spot urine protein-creatinine ratio with 24-hour urine protein excretion in women with preeclampsia
}

\section{G.Shreya *1, L. Pranathi ${ }^{2}$, V.Kavitha ${ }^{3}$.}

${ }^{*}$ Postgraduate, Department of Obstetrics and Gynaecology, Chalmeda Anand Rao Institute of Medical Sciences, Bommakal, Karimnagar, Talangana, India.

2 Professor, Department of Obstetrics and Gynaecology, Chalmeda Anand Rao Institute of M edical Sciences, Bommakal, Karimnagar, Talangana, India.

${ }^{3}$ Asst. Professor, Department of Obstetrics and Gynaecology, Chalmeda Anand Rao Institute of Medical Sciences, Bommakal, Karimnagar, Talangana, India.

\section{ABSTRACT}

Objective: To prospectively compare the results of spot urine protein-creatinine (P/C) ratio with 24-hour urine protein excretion in women with preeclampsia.

Materials and Methods: A total of 76 pregnant women with preeclampsia were prospectively studied for proteinuria at CAIM S, Karimnagar for a period of one year from August 2013 to July 2014. Urine P/C ratio was determined in a spot midstream sample, and the amount of protein excretion was measured in 24-hour urine collected on the subsequent day. The correlation between the spot $\mathrm{P} / \mathrm{C}$ ratio and 24 -hour urine protein excretion was assessed.

Results: There was a strong correlation between the spot $\mathrm{P} / \mathrm{C}$ ratio and 24-hour urine protein excretion ( $r=0.84$; $\mathrm{P}<.001$ ). The optimal spot $\mathrm{P} / \mathrm{C}$ ratio cut-off point was 0.20 for $300 \mathrm{mg} / 24 \mathrm{~h}$ of protein excretion (preeclampsia), with a sensitivity, specificity, positive predictive value, and negative predictive value of $91.2 \%, 87.8 \%, 94.4 \%$, and $96.8 \%$, respectively.A spot $\mathrm{P} / \mathrm{C}$ ratio less than 0.19 could exclude preeclampsia with a sensitivity of $100 \%$. Conclusions: We found that there is a significant correlation between the spot urine $\mathrm{P} / \mathrm{C}$ ratio and 24-hour urine protein excretion in women with preeclampsia. Urine $\mathrm{P} / \mathrm{C}$ ratio could be used for exclusion of preeclampsia. KEYWORDS: Urine protein: creatinine ratio, Preeclampsia, 24 hour urinary protein.

Address for correspondence: Dr. G.Shreya, Postgraduate, Department of Obstetrics and Gynaecology, Chalmeda Anand Rao Institute of Medical Sciences, Bommakal, Karimnagar, Talangana, India. Phone: 9440715201 E-M ail: gounishreya@yahoo.com

\begin{tabular}{|c|c|c|}
\hline \multicolumn{3}{|c|}{ Online Access and Article Informtaion } \\
\hline $\begin{array}{l}\text { Quick Response code } \\
\text { 口is? }\end{array}$ & \multicolumn{2}{|c|}{$\begin{array}{l}\text { International Journal of Integrative Medical Sciences } \\
\qquad \text { www.imedsciences.com }\end{array}$} \\
\hline Dol: 10.16965 ijims.2015.102 & $\begin{array}{l}\text { Received: 08-01-2015 } \\
\text { Reviewed: 08-01-2015 }\end{array}$ & $\begin{array}{l}\text { Accepted: } 20-01-2015 \\
\text { Published: 31-01-2015 }\end{array}$ \\
\hline Source of Funding: Self & \multicolumn{2}{|c|}{ Conflicts of interest: None } \\
\hline
\end{tabular}

\section{INTRODUCTION}

Preeclampsia is defined as a systolic blood pressure level of $140 \mathrm{~mm} \mathrm{Hg}$ or higher or a diastolic blood pressure level of $90 \mathrm{~mm} \mathrm{Hg}$ or higher that occurs after 20 weeks of gestation with proteinuria [1]. Proteinuria is an important sign of preeclampsia, and diagnosis is questionable in its absence.
Significant proteinuria is described as $300 \mathrm{mg}$ or more of urine protein per 24-hour period.

M easurement of protein excretion in a 24-hour urine collection has been the long-standing goldstandard but time consuming test for the quantitative evaluation of proteinuria induced by preeclampsia. A more rapid test capable of accurately predicting the results of a 24-hour 
urine would be valuable. An alternative method for quantitative evaluation of proteinuria is the measurement of protein-creatinine $(\mathrm{P} / \mathrm{C})$ ratio in a spot urine sample, which avoids the influence of variations in urinary solute concentration and provides a more convenient and rapid method to assess protein excretion.

The measurement of a random urine proteincreatinine $(\mathrm{P} / \mathrm{C})$ ratio has been tested as a substitute for the 24-hour urine protein excretion test for quantifying protein excretion in patients with renal diseases, such as diabetic nephropathy, lupus nephritis, and transplanted kidneys, with good correlation between the two methods [2-6]. The method relies on calculating the ratio of spot urine protein excretion to creatinine excretion and can normalize the protein excretion to the glomerular filtration rate. Therefore, a random urine $\mathrm{P} / \mathrm{C}$ ratio is not influenced by variations in hydration status [7]. However, because of the variety of the cutoff values among past studies [8-10], there is no uniform standard so the clinical usefulness of this test is still controversial.

The aim of the present study was to evaluate the ability of the random urine $\mathrm{P} / \mathrm{C}$ ratio to predict significant proteinuria, as well as to introduce a diagnostic test for preeclampsia that would avoid the inconvenience and time consumption of 24-hour urine protein collection.

\section{MATERIAL AND METHODS}

\section{Patients}

Pregnant women who were admitted in our obstetrics department with a suspicion of preeclampsia were studied prospectively. The study was conducted at Chalmeda ananda rao institute of medical sciences, karimnagar, a tertiary care centre, between August 2013 and July 2014, and the local ethics committee approved the study design.

Preeclampsia was defined as a blood pressure of $140 / 90 \mathrm{~mm} \mathrm{Hg}$ or higher after the 20th week of gestation measured twice at least 6 hours apart and a urine protein of $1+$ or greater by dipstick test or chronic hypertension without proteinuria before the 20th week accompanied by new-onset urine protein of 1+or greater by dipstick test. Women with the following condit- -ions were excluded: a known kidney disease, bacteriuria, bed rest longer than 24 hours, and gestational diabetes mellitus. In addition, women who delivered their babies during the urine collection day were excluded. A total of 76 pregnant women meeting the inpatient admission criteria for the evaluation of preeclampsia were prospectively recruited and provided informed written consent.

\section{Urine Tests}

Urine was collected for 24 hours. Immediately prior to the collection period, the patients also provided a spot midstream urine sample. The urine $\mathrm{P} / \mathrm{C}$ ratio was determined on spot urine specimens. The concentration of total protein in urine was measured by a biuret colorimetric assay and the urine creatinine level was measured by a modified Jaffe test. The urine P/ $C$ ratio was obtained by dividing the urinary protein concentration by the urine creatinine concentration. M easurements on the 24-hour urine sample were performed on the same day as collections were completed.

\section{Statistical Analyses}

The 24-hour urine protein excretion results were used as a gold standard in determining the cutoff points for the significant and severe proteinuria. Sensitivity, specificity, and positive and negative predictive values of random urine $\mathrm{P} / \mathrm{C}$ ratio were also calculated against this standard.The receiver operating characteristic (ROC) curve was used, and the area under the curve (AUC) was calculated. The relationship between the urine $\mathrm{P} / \mathrm{C}$ ratio and the 24-hour protein excretion was assessed with the Pearson correlation test. A P value less than .05 was considered significant.

\section{RESULTS}

A total of 114 pregnant women with preeclampsia were selected, of whom 38 were excluded because of gestational diabetes mellitus in 12 , bacteriuria in 12 , delivery before the completion of their 24-hour urine collection in 11, inadequate 24 -hour urine collection in 3 . Finally, 76 eligible pregnant women completed the study. Their mean age was $24.4 \pm 3.2$ years (range, 17 to 32 years). Four patients had preexisting hypertension with superimposed preeclampsia. 
Their mean gestational age was $35.2 \pm 3.6$ weeks (range, 23to 41 weeks). The median serum creatinine concentration was $0.62 \mathrm{mg} / \mathrm{dl}$, and the mean urinary protein excretion in 24-hour urine collections was $1.79 \pm 0.80 \mathrm{~g} / \mathrm{dl}$ (range: $135 \mathrm{mg} / \mathrm{dl}$ to $3000 \mathrm{mg} / \mathrm{dl}$ ).

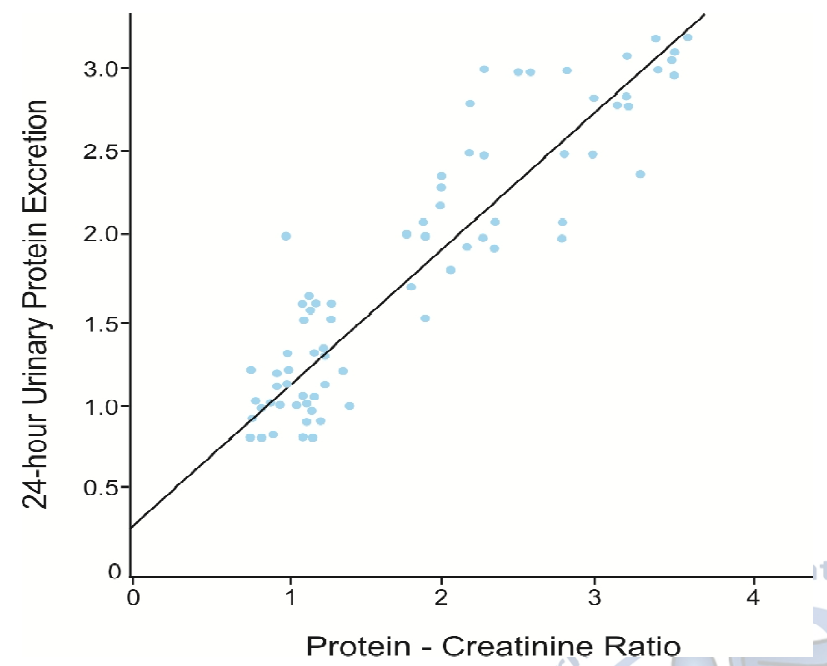

The mean $\mathrm{P} / \mathrm{C}$ ratio was $1.84 \pm 0.91$ (range, 0.42 to 3.58). The correlation coefficient for the $\mathrm{P} / \mathrm{C}$ ratio against the 24 -hour urine protein excretion was 0.84 . The regression equation was $Y=0.81 X+0.3(P<.001 ;$ Figure $)$ where $Y$ indicates urinaryprotein excretion $(g / 24 \mathrm{~h})$ and $X$ indicates $P / C$ ratio. By the ROC curve analysis, the $P / C$ ratio of 0.20 was identified as the best threshold to detect urine protein excretion of $300 \mathrm{mg} / 24 \mathrm{~h}$, with sensitivity and a specificity of $91.2 \%$ and $87.8 \%$, respectively. The positive and negative predictive values for $\mathrm{P} / \mathrm{C}$ ratios 0.20 were $94.4 \%$ and $96.8 \%$, respectively. A spot $\mathrm{P} / \mathrm{C}$ ratio less than 0.19 could exclude preeclampsia with a sensitivity of $100 \%$.

\section{DISCUSSION}

Preeclampsia is a significant contributor to maternal mortality and it affects $2 \%$ to $8 \%$ of all pregnancies [11]. One of the ways to diagnose preeclampsia, apart from the blood pressure criteria, is to look for the presence of significant proteinuria.

Several methods are available for measuring proteinuria but 24-hour urine protein excretion has long been regarded as the gold standard. However, this test has some disadvantages such as inconvenience for patients, inaccuracy due to incomplete collection, cost, and delay of diagnosis and management, which makes its wide use difficult for clinicians. One of the other methods most commonly used is the urinary dipstick test because of its simplicity and low cost. Nevertheless, this method has high false positive and false negative result rates associated with fluctuations throughout the day due to water intake, exercise, diet, posture, or improperly trained laboratory staff [12-14]. Thus a more rapid and accurate diagnostic test that is capable of predicting 24-hour urine protein excretion would be valuable.

Here, we propose the use of random urine $\mathrm{P} / \mathrm{C}$ ratio to facilitate prompt decision making by clinicians [15-16]. We prospectively determined the correlation between spot urine $\mathrm{P} / \mathrm{C}$ ratio and 24-hour urine protein excretion. Urine was collected from patients who met admission criteria for preeclampsia, and the spot value obtained at the beginning of the 24-hour collection period was compared to the result acquired from the 24-hour collection to see if these values were correlated. A good correlation between the spot urine $\mathrm{P} / \mathrm{C}$ ratio and 24-hour protein excretion has been demonstrated in patients with diabetic nephropathy, lupus nephritis, chronic kidney disease, and transplanted kidneys [3-6]. The National Kidney Foundation guidelines have suggested that spot urine samples should be used to detect and monitor proteinuria in children and adults [11].

In our study, a urine P/C ratio of 0.20 corresponded with a protein excretion rate of $300 \mathrm{mg} / 24 \mathrm{~h}$. These are characterized by excellent accuracy. Consistent with most previous studies with correlation coefficients ranging between 0.80 and 0.97 , we found a strong correlation $(r=0.84)$ between the spot $\mathrm{P} / \mathrm{C}$ ratio and the 24 -hour urine protein $[12,17$ 19]. However, using the spot $P / C$ ratio of 0.20 as a correlate to the critical value of $300 \mathrm{mg}$ of protein over 24 hours would result in the failure to identifysignificant proteinuria in approximately $8.8 \%$ ofaffected patients.

There are some reports with conflicting results. Because of the variability in laboratory methods for measuring proteinuria in different reported studies, several cut-off points and different units for the urinary $\mathrm{P} / \mathrm{C}$ ratio have been reported, thereby precluding valid comparisons among such studies [8-10]. 
Three systematic reviews have evaluated literature and have come to similar conclusions [20].

In an analysis by Cote et al, the spot $\mathrm{P} / \mathrm{C}$ ratio had a pooled sensitivity of $83.6 \%$ and specificity of $76.3 \%$ using a cut off of 0.26 to predict proteinuria $>300 \mathrm{mg} /$ day in a 24 hour collection, concluding that $\mathrm{P} / \mathrm{C}$ is a reasonable rule out test for excluding proteinuria [21].

Papanna et al, in an analysis suggested that a lower cut off of 0.130 .15 provides higher sensitivity but with more false positive results. A higher cut off of 0.6 to 0.7 had a higher specificity for significant proteinuria, but at a cost of lower sensitivity. Midrange ratios had poor sensitivity and specificity [22].

A more recent meta-analysis by $M$ orris RK et al including 2790 women had similar findings: a single diagnostic threshold of 0.3 had a sensitivity and specificity of $81 \%$ and $76 \%$ respectively. A lower cut off $(0.13)$ had better (89\%) sensitivity for exclusion of proteinuria [23].

Taken together, these data suggest that a urine $\mathrm{P} / \mathrm{C}$ ratio $>0.7$ strongly predicts significant proteinuria whereas a $\mathrm{P} / \mathrm{C}$ ratio $\varangle$.15 can be considered normal, so confirmation with 24 hour urine collection probably isn't necessary in these individuals [24]. If a 24 hour urine collection is not obtained, guidelines define proteinuria as random $\mathrm{P} / \mathrm{C}$ ratio $\geq 0.26$.

Our data suggested that the random urine $\mathrm{P} / \mathrm{C}$ ratio is a highly accurate test for discriminating between insignificant and significant proteinuria, as demonstrated by an area under the ROC curve of 0.92. The main concern in clinical use of this test is the false-negative test results, because $8 \%$ of patients with preeclampsia may be missed. To obtain the optimal cut-off, we selected the one that while increasing specificity maintains a sensitivity of higher than $90 \%$ in order to reduce the possibility of missing the diagnosis of preeclampsia.

Research in the future should be focused on the evaluation of clinical outcomes and the costeffectiveness of the use of a random urinary $\mathrm{P} /$ $C$ ratio for prediction of significant proteinuria. In addition, studying the test in an outpatient basis should be further considered in order to apply it in ambulatory management of preeclamptic patient. We suggest that further evaluations be done in order to determine a cutoff value for prediction of mild preeclampsia.

\section{CONCLUSION}

Based on the results of our study, we conclude that random urine $\mathrm{P} / \mathrm{C}$ ratios can predict 24-hour urine protein excretion with a high accuracy. This test can also be used as a reasonable alternative to 24-hour urine protein excretion, especially in emergency situations, and, it could also complement the urinary dipstick test in preeclamptic pregnancy.

\section{REFERENCES}

[1]. Cunningham FG, Gant NF, Leveno KJ, Gilstrap C, Hauth JC, Wenstrom KD, editors. Willams Obstetrics. 21st edition. New York: McGraw Hill; 2001. Hypertensive disorders in pregnancy; p. 568.

[2]. Shahbazian N, Hosseini-Asl F. A comparison of spot urine protein-creatinine ratio with 24-hour urine protein excretion in women with preeclampsia. Iran J Kidney Dis. 2008; 2:127-131.

[3]. Christopher-Stine L, Petri M, Astor BC, Fine D. Urine protein-to-creatinine ratio is a reliable measure of proteinuria in lupus nephritis. J Rheumatol. 2004; 31:1557-1559.

[4]. Chitalia VC, Kothari J, Wells EJ, Livesey JH, Robson RA, Searle M, et al. Cost-benefit analysis and prediction of 24-hour proteinuria from the spot urine protein-creatinine ratio. Clin Nephrol. 2001; 55:436-447.

[5]. Xin G, Wang M , Jiao LL, Xu GB, Wang HY. Protein-tocreatinine ratio in spot urine samples as a predictor of quantitation of proteinuria. Clin Chim Acta. 2004; 350:35-39.

[6]. Torng S, Rigatto C, Rush DN, Nickerson P, Jeffery JR. The urine protein to creatinine ratio $(\mathrm{P} / \mathrm{C})$ as a predictor of 24-hour urine protein excretion in renal transplant patients. Transplantation. 2001; 72:1453-1456.

[7]. Dwyer BK, Gorman M, Carroll IR, Druzin M. Urinalysis vs urine protein-creatinine ratio to predict significant proteinuria in pregnancy. J Perinatol. 2008; 28:461-467.

[8]. Yamasmit W, Chaithongwongwatthana S, Charoenvidhya D, Uerpairojkit B, Tolosa J. Random urinary protein-to-creatinine ratio for prediction of significant proteinuria in women with preeclampsia. J M atern Fetal Neonatal M ed. 2004; 16:275-279.

[9]. Zadehmodarres S, Razzaghi M R, Habibi G, Najmi Z, Jam H, M osaffa N, et al. Random urine protein to creatinine ratio as a diagnostic method of significant proteinuria in pre-eclampsia. Aust N ZJ Obstet Gynaecol. 2006; 46:501-504. 
[10]. Wheeler TL, 2nd, Blackhurst DW, Dellinger EH, Ramsey PS. Usage of spot urine protein to creatinine ratios in the evaluation of preeclampsia. Am J Obstet Gynecol. 2007; 196:465.e1-465.e4.

[11]. Keane WF, Eknoyan G. Proteinuria, albuminuria, risk, assessment, detection, elimination (PARADE): a position paper of the National Kidney Foundation. Am J Kidney Dis. 1999;33:1004-10

[12]. Saudan PJ, Brown M A, Farrell T, Shaw L. Improved methods of assessing proteinuria in hypertensive pregnancy. Br J Obstet Gynaecol. 1997; 104:11591164.

[13]. Bell SC, Halligan AW, Martin A, Ashmore J, Shennan $\mathrm{AH}$, Lambert PC, et al. The role of observer error in antenatal dipstick proteinuria analysis. $\mathrm{Br} J$ Obstet Gynaecol. 1999; 106:1177-1180.

[14]. Rizk DE, Agarwal M M, Pathan JY, Obineche EN. Predicting proteinuria in hypertensive pregnancies with urinary protein-creatinine or calciumcreatinine ratio. J Perinatol. 2007; 27:272-277.

[15]. Roudsari FV, Ayati S, Ayatollahi H, Shakeri MT. Protein/ creatinine ratio on random urine samples for prediction of proteinuria in preeclampsia. Hypertens Pregnancy. 2012; 31:240-242.

[16]. Sethuram R, Kiran TS, Weerakkody AN. Is the urine spot protein/creatinine ratio a valid diagnostic test for pre-eclampsia? J Obstet Gynaecol. 2011; 31:128-130.

[17]. Robert M, Sepandj F, Liston RM , Dooley KC. Random protein-creatinine ratio for the quantitation of proteinuria in pregnancy. Obstet Gynecol. 1997; 90:893-5.
[18]. Neithardt AB, Dooley SL, Borensztajn J. Prediction of 24-hour protein excretion in pregnancy with a single voided urine protein-to-creatinine ratio. Am J Obstet Gynecol.2002; 186:883-6.

[19]. Rodriguez-Thompson D, Lieberman ES. Use of a random urinary protein-to-creatinine ratio for the diagnosis of significant proteinuria during pregnancy. Am J Obstet Gynecol. 2001; 185:808-11.

[20]. Stout MJ, Scrifes CM , Stamillo DM . Diagnostic utility of urine protein-to-creatinine ratio for identifying proteinuria in pregnancy. J M atern Fetal Neonatal Med 2013:26:66.

[21]. Cote AM, Brown MA, Lam E, et al. Diagnostic accuracy of urinary spot: creatinine ratio for proteinuria in hypertensive pregnant women: systematic review. BMJ 2008; 336:1003.

[22]. Papanna R,M ann LK, Kouides RW, Glantz JC. Protein/ creatinine ratio in preeclampsia: a systematic review. Obstet Gynecol 2008; 112:135.

[23]. Morris RK, Riley RD, Doug M, et al. Diagnostic accuracy of spot urinary protein and albumin to creatinine ratios for detection of significant proteinuria or adverse outcome in patients with suspected pre-eclampsia: systematic review and meta-analysis. BMJ 2012; 345:E4342.

[24]. Visintin C, Mugglestone MA, Almerie MQ, et al. $M$ anagement of hypertensive disorders during pregnancy: summary of NICE guidance. BMJ 2010; 341: c 2207.

How to cite this article: G.Shreya, L. Pranathi, V.Kavitha. Comparison of spot urine protein-creatinine ratio with 24-hour urine protein excretion in women with preeclampsia. Int J Intg M ed Sci 2015;2(1):55-59. DOI:10.16965/ijims.2015.102 